\title{
BIOCHEMICAL ANALYSIS OF GENETIC RECOMBINATION IN EUKARYOTES
}

\author{
PATRICIA J. PUKKILA* \\ National Institute for Medical Research, The Ridgeway, Mill Hill, \\ London NW7 1AA, England
}

Received 20.v.77

\begin{abstract}
SUMMARY
Recent studies concerning molecular mechanisms of genetic recombination in eukaryotes are reviewed. Since many of these studies have focused on the testable predictions arising from the hybrid DNA theory of genetic recombination, this theory is summarised. Experiments to determine the time of meiotic crossing-over and the structure of the synaptonemal complex which facilitates meiotic crossing-over are described. Investigations of DNA nicking and repair events implicated in recombination are discussed. Properties of proteins which may facilitate hybrid DNA formation, and biochemical evidence for hybrid DNA formation are presented. Finally, a nuclease which has been implicated in gene conversion is described.
\end{abstract}

STUdies of the molecular events which result in recombination between chromosomes have been initiated in a wide variety of eukaryotic organisms. Since the meiocyte is a highly specialised cell which will produce specialised haploid progeny, the problem of identifying biochemical events which are strictly related to genetic recombination in the meiocyte are formidable indeed. In higher eukaryotes, the task of analysing genetic exchanges is further complicated by the striking evolutionary conservation of the number of reciprocal exchanges which occur in each meiosis. Although the amount of DNA can vary by orders of magnitude, the number of exchanges has remained quite limited.

The hybrid DNA theory as proposed by Holliday (1964) and Whitehouse and Hastings (1965) has become the focal point for experimental approaches. The scheme proposed by Holliday (1964) is still compatible with the available genetic data, and thus will be used as a basis for the discussion, in Section 1, of likely biochemical events during meiotic recombination. The first requirement which must be met to study the biochemical predictions which arise from this theory is to determine the time of meiotic crossing-over. The evidence, discussed in Section 2, strongly suggests that genetic exchange occurs during the pachytene stage of meiotic prophase. The prominent feature of the pachytene nucleus, which provides the framework for crossingover, is the synaptonemal complex, whose structure is reviewed in Section 3. DNA nicking and repair events implicated in hybrid DNA formation and recombination are evaluated in Section 4, and properties of DNA binding proteins which may facilitate this process are reviewed in Section 5. Biochemical evidence for hybrid DNA formation is presented in Section 6 and a nuclease implicated in gene conversion is described in Section 7.

* Present address: The Biological Laboratories, 16 Divinity Avenue, Cambridge, Mass. 02138, U.S.A.

$39 / 2-A$ 


\section{THE HYBRID DNA THEORY}

In Holliday's model (1964) nicks are introduced in single strands of the same polarity at corresponding sites in two homologous chromatids. These strands unravel, exchange positions, and reanneal with the complementary unnicked strand in the homologous chromatid, forming a half-chromatid chiasma and generating hybrid DNA on the two chromatids. The following events do not necessarily occur in the order in which they are described. The nicks at the origin of the hybrid DNA are ligated. The structure can isomerise so that the strands which had not been nicked now form the halfchromatid chiasma. The half-chromatid chiasma can migrate along the DNA, generating long stretches of hybrid DNA. The structure is resolved by the introduction of nicks which may or may not lead to the formation of a whole chromatid chiasma. If the hybrid DNA spans a region of heterozygosity in the genome, the mispaired bases may be corrected. The model thus provides an elegant basis for the specificity required for genetic exchange.

The model makes several specific biochemical predictions. First, an endonuclease is required to nick the chromatids in a highly specific manner. Biochemical studies of the nicking process are described in Section 4. The nuclease might recognise a specific linear sequence (Holliday, 1968). Alternatively, from studies of symmetry in protein-nucleic acid interactions (Sobell, 1973), Sobell has proposed that the nuclease might recognise a clover leaf Gierer loop (Sobell, 1972) or a sequence with two-fold symmetry (Sobell, 1975). Wagner and Radman (1975) have suggested that the nuclease might recognise a palindrome sequence. The common feature of these models is that potential sites for the initiation of hybrid DNA formation are limited by the occurrence of specific sequences. Thus mutant sites which lie close to the nuclease recognition sequence should be included in hybrid DNA more frequently than those which lie further away. Evidence supporting this prediction has come from genetic analysis of gene conversion in fungi. Gene conversion is aberrant segregation of alleles at a heterozygous locus giving ratios other than the expected 2:2 ratio within a tetrad (Lindegren, 1953; Mitchell, 1955). Presumably gene conversion is a consequence of mismatch repair in hybrid DNA. Conversion frequency appears to directly depend on the position of the allele within the gene (Lissouba et al., 1962) because alleles close to one end of the gene convert more frequently than those further away. This polarity in conversion frequencies appears to be a property of the gene and not a property of the gene position relative to the centromere (Murray, 1968). Some genes show more strict polarity than others (Lissouba et al., 1962; reviewed in Whitehouse and Hastings, 1965; Holliday, 1968).

Once the chromatids are nicked, the model predicts that by melting and reannealing the duplexes, a half-chromatid chiasma will form, associated with hybrid DNA on two chromatids. Proteins which facilitate the melting and renaturation of DNA are described in Section 5 and biochemical detection of hybrid DNA is discussed in Section 6. Molecular model building (Sigal and Alberts, 1972; Jeggo, 1973) has demonstrated that a half-chromatid chiasma can exist with no unpaired bases. Two further properties of the structure were predicted from the model building; strand isomerisation and branch migration. Strand isomerisation (Sigal and 
Alberts, 1972) causes the strands which do not cross in the half-chromatid chiasma to exchange places with the bridging strands. Sobell (1974) has studied the stereochemistry of isomerisation. He showed that it requires two $180^{\circ}$ rotations and predicted that the process will proceed more slowly than Sigal and Alberts (1972) envisaged, unless facilitated by a structural protein or endonuclease. Holliday (1977) has shown that when strand isomerisation occurs in association with the synaptonemal complex, the required rotations will be accomplished by looping the DNA molecules, since the ends of DNA molecules are anchored. Branch migration refers to the movement of the half-chromatid chiasma exchange point along the DNA in either direction. Meselson (1972) showed that rotary diffusion of two bacteriophage molecules (each 45,000 base pairs) was sufficient to generate 1000 base pairs of hybrid DNA in 20 seconds as a consequence of branch migration. Since the diffusion coefficient is inversely proportional to the length of the DNA, he proposed that the presence of rotational strain, single strand nicks, or proteins capable of unwinding supercoiled DNA ( $\omega$ proteins; Wang, 1971) might facilitate hybrid DNA formation in long chromatids.

The clearest genetic evidence for hybrid DNA on two chromatids is the occurrence of postmeiotic segregation in two pairs of spores (aberrant $4: 4$ segregation) from an octad (Kitani et al., 1962). Postmeiotic segregation (Olive, 1959) occurs when a haploid product of meiosis contains two alleles which segregate at the first (postmeiotic) mitosis. Presumably postmeiotic segregation occurs because mispaired bases in hybrid DNA are not corrected, and thus the haploid product contains genetic information for two alleles, one in each strand of the heteroduplex. In Sordaria (Kitani et al., 1962; Whitehouse and Hastings, 1965) and Ascobolus (Leblon and Rossignol, 1973) hybrid DNA appears to form regularly on two chromatids whereas in another strain of Ascobolus (Stadler and Towe, 1971) and in yeast (Fogel and Mortimer, 1970; Fogel, Hurst and Mortimer, 1971; Fogel and Mortimer, 1974) the results have been explained by assuming that hybrid DNA forms only on one chromatid. Meselson and Radding (1975) proposed that hybrid DNA is initially formed on one chromatid by asymmetric strand transfer, and subsequent isomerisation and branch migration can generate hybrid DNA on both chromatids. The asymmetric strand transfer could be energetically driven by DNA polymerase, and the asymmetric phase might predominate in organisms such as yeast. Holliday (1974) has shown that the data can be explained equally well by assuming that hybrid DNA is formed on both chromatids and migrates back and forth, so that the chance of correcting reciprocal regions in transient hybrid DNA may be small in organisms such as yeast.

Once hybrid DNA is formed, the mispaired bases may be corrected (giving gene conversion) or not corrected (giving postmeiotic segregation). The correction process appears to operate by recognition of the mismatched base, exonucleolytic digestion of a long tract of nucleotides, and repair synthesis. Conversion frequency and direction are marker specific (Rossignol, 1969; Leblon, 1972a; Leblon, 1972b) implying that some mismatches trigger the repair process more efficiently than others (reviewed in Sobell, 1973). Moore and Sherman $(1975 ; 1977)$ have studied recombination within sequenced portions of the yeast iso-l-cytochrome $c$ gene. Their studies have shown that different base pair changes at the same position within the gene 
could influence recombination frequency and also that changes in nearby base pairs could modify this influence. These marker effects are distinct from polarity in gene conversion discussed above, as the marker effects appear to derive from the mismatch involved (and perhaps the surrounding sequence) whereas the polarity effect appears to derive from the position of the marker within the gene. DNA repair events in meiotic prophase are discussed in Section 4 and a nuclease which has been implicated in the recognition of mismatched bases during gene conversion is described in Section 7. The correction is not a strictly local cvent but involves degradation of about 1000 nucleotides and resynthesis (Fogel and Mortimer, 1969). This type of repair is necessary to explain co-conversion in which two mutant sites which lie close together within the same region of hybrid DNA are not repaired independently but are converted simultaneously (Fogel and Mortimer, 1969). Fincham and Holliday (1970) have used an excision repair hypothesis to construct a mathematical model which predicts why markers spaced widely within a gene appear to recombine more frequently than expected from summing recombination frequencies between more closely spaced markers within the same gene (fine structure map expansion). Their model further predicts that degradation of single DNA strands can proceed in either chemical direction from a mismatched base pair. Leblon and Rossignol (1973) have shown that conversion at one site can decrease postmeiotic segregation at a closely linked site, which provides strong evidence in support of the hypothesis that gene conversion proceeds by the correction of heterozygosity. Models for recombination which do not necessitate heteroduplex correction for gene conversion (Stahl, 1969; Paszewski, 1970) thus appear to be incorrect (Holliday and Whitehouse, 1970; Hastings, 1975).

The half-chromatid chiasma can be resolved in several ways. Until the original nicks are ligated, diffusion of the half-chromatid chiasma back to its origin will cause the bridge to disappear. Once the original nicks are ligated, further nicks are required to resolve the structure. If the additional nicks occur in strands which were not previously nicked, then a reciprocal exchange between the chromatids occurs, and a whole chromatid chiasma is formed. This visible switch in pairing partners is apparent at diplotene. Depending on the composition and fate of the hybrid DNA present in the chromatids, the reciprocal exchange may be associated with non-reciprocal events within the hybrid DNA. If the additional nicks occur in the previously nicked strands, then no chiasma is formed, although postmeiotic segregation and gene conversion can occur. Hurst, Fogel and Mortimer (1972) have shown that in yeast, 50 per cent of gene conversion events are associated with reciprocal exchange which produces a non-parental configuration of flanking markers. Such a result is predicted if the two ways to resolve the half-chromatid chiasma by nicking discussed above occur with equal probability.

The model thus predicts how breakage and reunion of chromosomes can be accomplished in a very precise way. Since most of the chromatin is highly condensed when meiotic recombination occurs, it is clear that the condensation process must be carefully regulated if hybrid DNA formation between homologues is to occur. The first level of condensation of DNA in chromatin as proposed by Kornberg (1974) is the coiling of the double helix around the histone tetramer core, forming a nu body or nucleosome 
(for recent model, see Weintraub et al., 1976). Chromatin in the electron microscope appears as "beads on a string" (Olins and Olins, 1974). The regular packaging of DNA in these nucleosomes is revealed by nuclease digestion (Hewish and Burgoyne, 1973; Noll, 1974) which releases 200 base pair fragments from chromatin. High order condensation of these nucleosomes has been studied by Benyajati and Worcel (1976) who isolated intact genomes from Drosophila melanogaster tissue culture cells and studied their structure after ethidium bromide intercalation and DNase, RNase, and pronase digestion. They propose that nucleosomes in interphase chromatin are segregated in chromomere sized domains of supercoiled loops which can be relaxed independently. It is likely that chromatin in pachytene chromosomes also contains supercoiled domains of nucleosomes which can be selectively relaxed. Proteins which can unwind supercoils ( $\omega$ proteins, Wang, 1971) have been detected in secondary mouse embryo cells (Champoux and Dulbecco, 1972), nuclei from mouse and human cell lines (Vosberg et al., 1974), Drosophila eggs (Baase and Wang, 1974), Xenopus oocytes (Mattoccia et al., 1976), and an $\omega$ protein has been purified from human tissue culture cells (Keller, 1975). The activity of these proteins during meiotic prophase and the control of supercoiling in meiotic chromatin are exciting topics for future research. Observations concerning the special qualities of the premeiotic S phase (Callan and Taylor, 1968; Callan, 1972; Callan, 1973; Hotta and Stern, 1971b), the unusual properties of meiotic histones (Sheridan and Stern, 1967; Bogdanov et al., 1968; Strokov et al., 1973; Nadler, 1976), and the altered nucleosome arrangement in meiotic chromatin (Stern and Hotta, 1977) may also be relevant to understanding how the careful control of meiotic chromosome condensation is achieved.

Throughout this discussion, the occurrence of recombination at a limited number of specific sites in the genome has been emphasised. Thuriaux (1977) has presented a compelling argument which suggests that recombination is confined to structural genes in eukaryotes. He tabulated the DNA content (which varies by orders of magnitude), the total map distance of the genome (which varies over a narrow range), and the map distance of individual structural genes (which varies over a small range) for several eukaryotic species. He then argued that if recombination were random, then the chance of recovering a recombinant within a structural gene should decrease with increasing genome size (i.e. the map distance should decline in proportion to the increase in DNA content) since neither the number nor size of structural genes nor the total number of exchanges appears to vary with DNA content. Thus recombination and repair of heteroduplex DNA are expected to be largely confined to structural genes. However, observations on diplotene lampbrush chromosomes indicate that visible chiasmata are not localised within structural genes. Callan and Perry (1977) have pointed out that chiasmata are never found in lateral loops of lampbrush chromosomes. Transcription of 5 S genes (Pukkila, 1975), histone genes, globin genes, and genes coding for other mRNAs (Sommerville and Malcolm, 1976; Callan and Old, personal communication) has been demonstrated on lateral loops and it is likely that recombination can occur within these genes. Thus it appears that when recombination occurs within a gene which will be transcribed in diplotene the chiasma must move from the site at which recombination occurred to the adjacent chromomere, where the visible chiasma is stabilised. 
In summary, genetic recombination requires precise alignment of homologous chromosomes which are condensed in a carefully regulated fashion. Recombination is initiated by single strand nicking at specific sites in the genome and requires DNA binding proteins, DNA ligase, endonuclease and polymerase to repair heterozygosity, endonuclease to resolve the half-chromatid chiasma, and proteins to stabilise the chiasma. It is likely that genetic recombination is confined to structural genes in higher eukaryotes and thus repair of heterozygosity in hybrid DNA probably occurs predominantly in unique sequences.

\section{The time OF GROSSING-OVER}

As yet there is no definitive answer to the simplest question which one might pose concerning genetic recombination in meiosis: when does it occur? A useful approach to this problem has been to determine the time of various events in meiotic prophase (such as premeiotic DNA synthesis and synapsis) and determine when recombination frequency (measured directly or inferred from chiasma frequency) can be altered by the application of perturbing agents (Peacock, 1968; Peacock, 1970). It is clear that there are several discrete stages ranging from premeiotic mitosis through the end of pachytene during which recombination frequency can be altered by temperature shock, irradiation, or metabolic inhibitors. These agents undoubtedly have multiple effects and thus the responses are not uniform among organisms (tabulated in Westerman, 1967; reviewed by Henderson, 1970). Markers on different chromosomes do not always respond the same way (e.g. Yost and Benneyan, 1957), and neither do markers in different regions of the same chromosome (e.g. Chandley, 1968). Within the same chromosome interval, intragenic and intergenic recombination can show different responses to the same agent (Lawrence, 1965; Lawrence, 1967). In most of the experiments, it is not clear whether preconditions for exchange or the ongoing process of exchange are being perturbed. This distinction has been drawn by Baker et al. (1976) in their review of the genetic control of meiosis. It appears that the distribution of potential sites for exchange and the frequency with which exchanges occur are under separate but overlapping genetic controls. Since the last stage during which recombination frequencies can be altered is pachytene, when the chromosomes are properly aligned and associated with the synaptonemal complex, it is likely that crossing-over occurs at this stage (Henderson, 1970).

An alternative approach which can perhaps be applied to meiocytes was developed by Holliday (1971) to determine the time of ultraviolet radiation induced recombination in mitotic cells of Ustilago maydis. A diploid was constructed which lacked nitrite reductase (nir/nir) and also contained two non-complementing alleles of the inducible nitrate reductase gene in trans (nar 1-12+/+nar 1-13). Recombination within the nar gene allows synthesis of functional enzyme which reduces nitrate to nitrite. The assay for nitrite is sensitive enough to enable recombination to be detected at a frequency of one in 10,000. The method thus depends only on the transcription and translation of the nar ${ }^{+}$gene and not the survival of the cell for recombination to be detected. The technique was used to show that mitotic recombination stimulated by a temperature sensitive block in DNA synthesis occurred during, not after, the period of inhibition (Unrau and Holliday, 1972). 
Hopefully, a similar method can be applied to meiotic cells to provide direct evidence for the time of crossing-over as opposed to commonly used methods which reveal the times at which recombination can be perturbed.

\section{The Synaptonemal COMPLEX}

Since its discovery by Moses in 1956, the synaptonemal complex has been found to be almost universally associated with crossing-over during the pachytene stage (reviewed in Moses, 1968; Westergaard and von Wettstein, 1972; Gillies, 1975). Exceptions to this rule have been reported. Podospora anserina does not have well defined synaptonemal complexes although crossingover occurs (Zickler, 1973). Female Bombyx mori chromosomes do not undergo meiotic recombination but do have synaptonemal complexes (Rasmussen, 1976). Synaptonemal complexes are often present in haploid plants (Gillies, 1974) accompanied by very little, if any, crossing-over. In general, synaptonemal complex formation occurs between homologous segments of chromosomes, although exceptions have been documented (Rhoades, 1968). Recombination does not appear to take place between non-homologous segments.

The tripartite structure of the synaptonemal complex is remarkably uniform in eukaryotes, although the ratio of synaptonemal complex length to DNA length ranges from $1: 100$ in yeast (Byers and Goetsch, 1975) to $1.5: 10,000$ in maize (Gilles, 1973). The lateral elements are proteinaceous rods with a diameter of $300 \AA-600 \AA$ which may contain RNA (Westergaard and von Wettstein, 1970; Esponda and Stockert, 1971) and histones (Strokov et al., 1973). Each lateral element is associated with the two chromatids of a replicated chromosome. After chromosome pairing, the lateral elements are held $1000 \AA$ apart by the central region. The presence of DNA in the central region has not been conclusively demonstrated. The central component is also proteinaceous and appears to be assembled in situ in Locusta (Moens, 1969) but transported from the nucleolus in Neottiella (Westergaard and von Wettstein, 1970). Using serial reconstruction, Carpenter (1975a) has documented that the length of the completed synaptonemal complex is not fixed in Drosophila but decreases by 50 per cent and then increases as the cells progress through pachytene. In maize, only the peripheral chromatin is thought to contract (Gillies, 1975) and in Locusta, chromosome contraction appears to be associated with shedding of lateral elements and buckling of the central region (Moens, 1973). After being shed from the chromosomes in diplotene, synaptonemal complexes appear to aggregate together in stacks which have been called polycomplexes (Roth, 1966; Moses, 1968; Dudley, 1973; Fiil and Moens, 1973; Zickler and Olson, 1975; Rasmussen, 1975). Some synaptonemal complex persists around the chiasmata and may help to stabilise these structures (Westergaard and von Wettstein, 1972). Perhaps the purification of synaptonemal complex proteins, so critical to an understanding of their function, can be facilitated by their DNA binding and self-association properties.

The preliminary movement of homologous chromosomes to within 3000 A so that cross-connecting filaments can be laid down within the synaptonemal complex has been studied by light and electron microscopy, genetic manipulation, and biochemical perturbation. The meiocyte is usually able to avoid bivalent interlocking, suppress homoeologous pairing (reviewed in 
Sears, 1976) and still permit rearranged segments within chromosomes to pair precisely. Three mechanisms have been described which may facilitate the pairing process: pre-alignment of homologues, the association of telomeres with the nuclear envelope, and replication of spccific DNA sequences.

The evidence for pre-alignment has been reviewed by Grell (1969). Compelling evidence for pre-alignment in Triticum was provided by Driscoll and Darvey (1970) who showed that colchicine treatment prior to meiotic prophase reduced chiasma formation between homologous chromosomes but not between the arms of an isochromosome, whose homologues are held together by the centromere. Dover and Riley (1973) determined that colchicine applied during the last premeiotic mitosis induced asynapsis in Triticum. These workers concluded that the drug interfered with the premeiotic anaphase movements which align homologous chromosomes. Buss and Henderson (1971) also concluded that pre-alignment during the premeiotic mitosis was critical to proper chromosome pairing, since heat shock administered at this time in Locusta caused a reduction in chiasma frequency and induced bivalent interlocking. Maguire (1977) has observed prealignment during the premeiotic metaphase in Zea. However, it is clear that pre-alignment does not always occur, since in Neottiella and Chlamydomonas, homologous chromosomes are in separate nuclei during prerneiotic S phase (Rossen and Westergaard, 1966; Westergaard and von Wettstein, 1970; Sueoka et al., 1967). Pre-alignment is thought to be necessary to avoid interlocked bivalents, since synaptonemal complex formation is often initiated at more than one site (Moens, 1968; Gillies, 1975). However, recent evidence suggests that at least one organism can resolve interlocked bivalents after substantial portions of the synaptonemal complex have been completely assembled (Rasmussen, 1976).

Attachment of the telomeres to the nuclear envelope during leptotene has been well documented by serial reconstruction (Moens, 1969). However, the attachment sites for homologous chromosomes can be widely separated, so they must slide within the nuclear envelope during pachytene (Moens, 1969). Two observations indicate that the pairing of homologous telomeres is not the only way in which chromosome pairing is achieved. First, synaptonemal complex formation can be initiated at multiple internal sites (Moens, 1968; Gillies, 1975). Second, inverted or translocated chromosome segments can often pair precisely (Westergaard and von Wettstein, 1972; Maguire, 1977).

DNA replication during zygotene appears to have a role in synaptonemal complex formation in Lilium. The zygotene DNA (Z DNA) synthesis in Lilium has been extensively studied (Hotta et al., 1966; Roth and Ito, 1967; Stern and Hotta, 1969; Hotta and Stern, 1971b; Hecht and Stern, 1971; Stern and Hotta, 1973; Hotta and Stern, 1976; Stern and Hotta, 1977). Briefly 0.3 per cent of the genome $\left(3 \times 10^{8}\right.$ base pairs per haploid genome) which occurs in stretches of roughly 10,000 base pairs spaced $3 \times 10^{6}$ base pairs apart and consists of unique sequence DNA with 50 per cent $\mathrm{G}+\mathrm{C}$ content remains unreplicated during premeiotic interphase and early prophase. Since no single stranded DNA is detectablc in these cells, it is assumed that the newly replicated chromatids are held together at the unreplicated duplex (Stern and Hotta, 1977). During their replication in zygotene, these regions become transiently associated with newly synthesised protein in a lipoprotein complex (Hecht and Stern, 1971). The semi- 
conservative nature of this synthesis was demonstrated by saturation hybridisation and BUdR incorporation (Hotta and Stern, 1971b). If cells are explanted just after premeiotic $\mathrm{S}$, they revert to mitotis, and semiconservative replication of these sequences occurs before the division (Stern and Hotta, 1969). In meiocytes, the newly synthesised strands are not ligated to chromosomal DNA until chromosome disjunction (Hotta and Stern, 1976). The persistence of these flanking gaps (which can be cured in vitro with polymerase and ligase, but not with ligase alone) renders the DNA susceptible to shear and to $\mathrm{S}_{1}$ nuclease so that $\mathrm{Z}$ DNA bands as a satellite $(\mathrm{P}=1.712)$ in caesium chloride (Hotta and Stern, 1976; Stern and Hotta, 1977). If prepared from gently lysed protoplasts and sedimented in glycerol gradients, labelled Z DNA co-migrates with bulk DNA in neutral but not alkaline gradients (Hotta and Stern, 1976). Such high molecular weight material should not show the Z DNA satellite in caesium chloride if all the sequences are chromosomal, but this experiment was not pursued for technical reasons. Ribosomal RNA does not hybridise to Z DNA (Stern and Hotta, 1973). Electron-microscopic visualisation of $\mathrm{Z}$ DNA, which might help to clarify the nature of these sequences by, for example, revealing single strand ends or episomic circular material, has not been reported.

The significance of Z DNA remains unclear. Autoradiographic analysis suggested that it is scattered over all the chromosomes (Ito and Hotta, 1973). If deoxyadenosine, which prevents DNA synthesis, is applied in zygotene, a spectrum of effects from the total cessation of meiosis through chromosome breaks in anaphase II is observed, depending on the concentration and time of treatment (Ito et al., 1967). Such cells show arrest of pairing with no further formation of the synaptonemal complex (Roth and Ito, 1967). However, deoxyadenosine had no effect on post-pachytene cells which is surprising since curing of the flanking Z DNA gaps is expected to occur after pachytene. If cells are treated with cyclohexamide (which stops protein synthesis) in zygotene, Z DNA synthesis is inhibited (Hotta et al., 1968) and chromosomes are achiasmatic (Parchman and Stern, 1969). Colchicine treatment does not affect Z DNA synthesis (Hotta and Shepard, 1973) although this treatment does lead to achiasmatic chromosomes.

In wheat and rye, DNA synthesis has been detected throughout meiosis by autoradiography (Riley and Bennet, 1971) and by biochemical analysis (Flavell and Walker, 1973). The DNA synthesised during zygotene had a slightly heavier buoyant density than the main peak. When zygotene DNA synthesis was inhibited with deoxyadenosine, synapsis was not prevented and chromosome fragmentation was not observed (Flavell and Walker, 1973).

Stern and Hotta (1977) have called Z DNA " the centerpiece of zygotene metabolism" and feel that Z DNA replication and transient association with the nuclear envelope may be directly involved in chromosome pairing. Studies of meiotic cytology in lilies (Dickinson and Heslop-Harrison, 1977) have revealed pronounced changes in the cytoplasmic membrane. Up to 15 per cent of microsporocyte cytoplasm is encapsulated by membrane, which resembles nuclear membrane morphologically in that pores are present. Although purified nuclei were used to obtain the Z DNA-lipoprotein complex, cytoplasmic contamination appears to be a factor to consider. The evidence for a role of $\mathrm{Z}$ DNA in pairing comes largely from the deoxyadenosine experiments. Synaptonemal complex formation appears 
to depend on the completion of Z DNA replication (Roth and Ito, 1967). However, in yeast, only the initiation of premeiotic DNA synthesis appears to be necessary for synaptonemal complex formation (Simchen and Hirshberg, 1977). Several alternative functions for Z DNA sequences remain to be explored. Are they always chromosomal or can they exist as episomal elements? Are they transcribed in meiocytes, and do their unusual properties derive from the necessity to keep them available for transcription? Do they serve a structural role (e.g. as binding sites for synaptonemal complex proteins or fibrillar pairing proteins, or as swivel points to relieve rotational strain during chromosomal condensation or hybrid DNA formation)? Perhaps the new techniques for cloning specific fragments of eukaryotic DNA by attaching these to plasmid or phage vectors and selecting specific sequences for study can be used to facilitate further study of Z DNA structure and function.

The processes which regulate the frequency and distribution of exchanges during meiosis must involve the association of chromatin with the synaptonemal complex in a highly specific way. Maguire $(1965,1966,1972,1977)$ has proposed a specific hypothesis for the control of recombination frequency by the synaptonemal complex. In situations in maize where synapsis may or may not occur (in cells with inversions or translocations) recombination is not proportional to the genetic length of such segments but rather corresponds to the frequency of synapsis in these regions. Thus, synapsis may not be a precondition for exchange but may coincide with commitment to recombination in a given region. However, Rhodes (1968) showed that synapsis can occur between non-homologous chromosome segments in maize, with a consequent decrease in crossing-over. These results suggest that the initiation of pairing and the commitment to recombination are separate processes.

In considering how the synaptonemal complex might regulate the distribution of exchanges, Holliday (1977) has proposed a general mechanism to account for interference. It is known that reciprocal exchanges interfere with one another, but non-reciprocal exchanges show no interference. Chiasmata are not randomly distributed among the chromosomes and structural heterozygosity which leads to imperfect synaptonemal complex formation can result in an increased number of reciprocal exchanges elsewhere in the genome. Holliday (1977) summarised these observations and proposed that a limited amount of a DNA binding protein which becomes trapped in completed synaptonemal complexes stabilises potential chiasmata and controls their distribution. Non-reciprocal exchanges do not require such stabilisation and thus do not show interference. Electron-microscopic investigation has revealed the presence of nodules associated with the synaptonemal complex whose frequency and position are correlated with the occurrence of recombination (Carpenter, 1975b). These nodules might represent a complex containing the agent which stabilises potential chiasmata. Similar structures have bcen observed in synaptonemal complexes of Neurospora (Gillies, 1972), Lilium (Moens, 1968) and in unpaired lateral elements during synaptonemal complex formation in Lilium.

\section{DNA NIGKING AND REPAIR DURING PAGHYTENE}

In Chlamydomonas, inhibitors of DNA synthesis applied in what was assumed to be pachytene altered recombination frequencies (Davies and 
Lawrence, 1967). Chiu and Hastings (1973) explained results with various inhibitors of DNA synthesis by assuming that recombination is proportional to the number of replicons which fail to initiate DNA synthesis during premeiotic S. The argument rests on the observations that mitomycin $\mathbf{C}$ and phenethyl alcohol inhibit DNA synthesis after a delay in vegetative cells and lead to an increase in recombination frequency in one tested interval when applied during meiotic prophase whereas FUdR, naladixic acid and hydroxyurea inhibit DNA synthesis with no delay and lead to a decrease in recombination frequency in the interval. The hypothesis could be further tested by examining other genetic intervals, demonstrating the actual targets for the inhibitors (e.g. initiation or elongation) in meiotic cells, and testing the prediction that recovery synthesis after mitomycin $\mathrm{C}$ and phenethyl alcohol is highly localised. The most serious objection to the hypothesis is that the main period of DNA replication in the zygote may be a postmeiotic synthesis. Sueoka et al. (1967) have shown that there is only one round of DNA replication in a zygote which produces eight haploid products. The premeiotic $S$ appears to occur in the gamete before fusion (as occurs in Neottiella; Rossen and Westergaard, 1966) and the DNA replication in the zygote is probably in preparation for a postmeiotic mitosis. The inhibitors could be acting on repair replication during pachytene. However, effects on RNA and protein synthesis were also noted, which could have produced the reported changes in recombination frequency.

In Coprinus, Lu and Jeng (1975) found a surprisingly high level of incorporation of ${ }^{32} \mathrm{P}$ into DNA during pachytene (50 per cent of the amount which occurred during premeiotic $\mathrm{S}$ !) but the significance of this finding is difficult to assess since the DNA was extracted from basidiocarps, and thus the contribution of cytoplasmic DNA can not be assessed. In yeast, mitochondrial DNA synthesis occurs throughout meiosis (Kuenzi and Roth, 1971) and preferential labelling of mitochondrial DNA has been observed at specific stages during sporulation (Pinon et al., 1974). In Coprinus the incorporation did not occur at low temperature ( $\mathrm{Lu}$ and Chiu, 1976). The low temperature treatment led to increased recombination, the effect being proportional to the time of treatment $(\mathrm{Lu}, 1974)$. Heat treatment led to an increase in recombination and increase in the amount of repair synthesis. They propose that DNA is randomly nicked during prophase and that the low temperature treatment prevents repair synthesis. The longer the nicks remain unpaired, the greater the chance that nicks at homologous sites can "match" and lead to crossing-over, with repair synthesis occurring at normal levels during the recovery period. Heat treatment is thought to increase the number of nicks, thus increasing recombination and repair synthesis. Since neither nicking of chromosomal DNA in pachytene nor repair of these hypothetical breaks has been directly demonstrated, their hypothesis to explain the altered recombination frequency remains largely speculative.

In yeast, single strand nicks in chromosomal DNA extracted from sporulating cells have been demonstrated by Jacobson et al. (1975) using sedimentation analysis. The possible contribution of mitochondrial DNA in this analysis was excluded. No changes in the sedimentation pattern of double-stranded DNA were detected during sporulation. However, after a brief exposure to sporulation medium, a noticeable reduction in molecular weight of single stranded DNA was observed. After a few hours 
in sporulation medium, substantially more high molecular weight singlestranded DNA was seen, and the profiles resembled those from logarithmic vegetative cells. Between 10 and 18 hours (when commitment to recombination takes place), a decline in the amount of high molecular weight material was noted, consistent with the introduction of two to six nicks per $1.5 \times 10^{6}$ base pairs of DNA per $4 \mathrm{C}$ nucleus. If one nick were required to initiate a recombination event, then four nicks per $1.5 \times 10^{6}$ base pairs per nucleus would be expected. The calculation was based on the DNA content of yeast $\left(5.5 \times 10^{7}\right.$ base pairs per $4 \mathrm{C}$ nucleus) and on the total number of expected recombination events per meiocyte (150). The repair of these nicks leading to the return of high molecular weight DNA after 18 hours could not be examined due to difficulties in preparing spheroplasts. Although the correlation (approximately one nick per recombination event) suggests a functional relationship between nicks and recombination, caution must be exercised in interpreting the experiment, especially in the light of the effects produced by brief exposure to sporulation medium.

Commitment to recombination in yeast (as defined by the time of appearance of meiotic recombinants when cells are removed from sporulation medium and returned to vegetative medium) occurs before commitment to meiotic disjunction (Esposito and Esposito, 1974). Commitment to recombination appears to require the initiation, but not the completion, of premeiotic DNA synthesis (Simchen and Hirshberg, 1977). Since synchrony in sporulating cells relative to the duration of meiosis is rather poor with techniques now available, the arguments for repair synthesis after completion of replication are largely indirect. Silva-Lopez et al. (1975) concluded that hydroxyurea can act after the completion of premeiotic DNA synthesis to prevent repair replication necessary for recombination. In transferring cells from sporulation medium to sporulation medium containing hydroxyurca, they found that in a population in which one-third of the cells had completed DNA replication (as judged by their ability to form viable spores), only 10 per cent of the committed recombinants were stable in the presence of the drug. Simchen et al. (1976) described a hydroxyurea-sensitive stage after premeiotic $\mathrm{S}$ and found that the drug caused DNA degradation and led to cell death.

In lilies, two lines of evidence indicate that repair replication takes place during pachytene at $6 \times 10^{5}$ sites per haploid genome (Hotta and Stern, 1971 $b$; Howell and Stern, 1971 ; Smyth and Stern, 1973; Hotta and Stern, 1974; Stern and Hotta, 1973; Hotta and Stcrn, 1975; Stern and Hotta, 1977). Approximately 0.1 per cent of the genome $\left(1 \times 10^{8}\right.$ base pairs per haploid genome) undergoes hydroxyurea-insensitive repair replication during pachytene (P DNA). Incorporation occurs into both old and new strands of DNA purified from isolated nuclei and is sufficiently scattered throughout the genome so that no density shift is produced after labelling in the presence of BUdR even after the DNA is sheared to $1 \times 10^{3}$ base pairs (Hotta and Stern, 1971 b). From these results, Howell and Stern (1971) calculated that the minimum number of regions undergoing repair replication per genome is $6.6 \times 10^{5}$ although the calculation was very approximate. The reassociation kinetics of $\mathrm{P}$ DNA indicate that it is moderately repeated (2000-3000 copies) in the genome (Smyth and Stern, 1973) and pyrimidine tract analysis revealed a different pattern from $\mathrm{S}$ phase DNA (Hotta and Stern, 1975). DNA labelled in pachytene following 
$\mathrm{X}$ irradiation reassociated in a more complex fashion, indicating that repair is not necessarily confined to repeated sequences in pachytene (Stern and Hotta, 1977). In considering the total amount $\left(1 \times 10^{8}\right.$ base pairs $)$ kinetic complexity $\left(5 \times 10^{4}\right.$ base pairs $)$ and distribution $\left(6 \times 10^{5}\right.$ sites $)$ of $\mathrm{P}$ DNA in the haploid genome, it appears that there are about 170 nucleotides present at each of the $6 \times 10^{5}$ sites. There are about 300 sets of these sequences, each set containing about $2 \times 10^{3}$ copies. These calculations are imprecise since all pachytene sequences may not label simultaneously and some $\mathrm{P}$ DNA is less highly repeated. Attempts to demonstrate P DNA by autoradiography were unsuccessful since most of the grains resulting from incorporation of ${ }^{3} \mathrm{H}$ thymidine during pachytene (but not at other stages) were DNase insensitive (Ito and Hotta, 1973). Another curious feature of $\mathrm{P}$ DNA is that its distribution in caesium chloride gradients is not uniform. Labelled P DNA regularly bands under the main peak of DNA, but the radioactivity is clustered in discrete peaks (Hotta and Stern, 1971b). It is hard to see how such clustering would occur if the P DNA sequences are uniformly scattered in the genome.

Sedimentation analysis revealed no changes in native DNA extracted from protoplasts as cells proceeded through meiosis (Hotta and Stern, 1974). When single-stranded DNA (labelled during premeiotic S) was examined, about half sedimented with a modal value of $104 \mathrm{~S}$ at all stages. However, a striking change in the pattern was observed during pachytene. About half of the DNA sedimented at $62-65 \mathrm{~S}\left(1.4 \times 10^{5}\right.$ bases $)$, the rest sedimenting at $104 \mathrm{~S}\left(5.2 \times 10^{5}\right.$ bases $)$. An achiasmatic hybrid did not show this pattern, nor did cells rendered achiasmatic by cyclohexamide or colchicine treatment, or cells irradiated at prepachytene stages. DNA labelled during pachytene sedimented at $104 \mathrm{~S}$. No chase of label from the $62 \mathrm{~S}$ peak could be demonstrated, due to lack of material. Since each chromatid contains two single strands of $7.6 \times 10^{9}$ bases, it is apparent that considerable nicking occurred at all stages to produce the $104 \mathrm{~S}$ peak. Considering the nicks which appear at pachytene $\left(2.4 \times 10^{6}\right.$ per cell $)$ and the observed number of chiasmata (36 [Sen, 1969]) there are $6.7 \times 10^{4}$ nicks for each reciprocal exchange.

Enzyme activities have been described which can introduce single-strand nicks (leaving $5^{\prime} \mathrm{OH}$ groups), phosphorylate these, dephosphorylate the $3^{\prime} \mathrm{PO}_{4}$ groups and ligate them during pachytene (Howell and Stern, 1971), but no exonuclease activity was described. The activity of the endonuclease increased during meiotic prophase until pachytene and fell thereafter. The other activities remained roughly constant, although Dickinson and HelsopHarrison (1977) have reported a cyclic variation in acid phosphatase activity during meiotic prophase in lily. It is assumed that the repair replication occurs at the nicked sites, since $6.6 \times 10^{5}$ sites of replication and $6 \times 10^{5}$ sites of nicking have been estimated per haploid genome, but it is clear that the overlap cannot be complete, since the gaps adjacent to the Z DNA stretches are not repaired during pachytene.

Observations of similar patterns of pachytene DNA metabolism have been described in mouse spermatocytes. Initial attempts to demonstrate DNA synthesis during pachtyene during autoradiography were unsuccessful (Kofman-Alfaro and Chandley, 1970). When cultured in vitro, spermatocyte pachytene nuclei incorporated ${ }^{3} \mathrm{H}$ thymidine to detectable levels (KofmanAlfaro and Chandley, 1971) although the incorporation could have been 
an artifact resulting from the culture conditions (Meistrich et al., 1975) since the cells fail to differentiate through prophase in culture. However, in recent experiments (Hotta et al., 1977), single-strand nicking of mouse spermatocyte pachytene DNA (labelled in vivo) was demonstrated by sedimentation analysis, and hydroxyurea-insensitive repair replication was shown to occur predominantly in repeated sequences. Cells in various stages of meiotic prophase were purified by gravity sedimentation (Chandley et al., 1977) and gently lysed for DNA sedimentation analysis. The possible contribution of cytoplasmic DNA was not considered. About half of the single-stranded DNA from the pachytene-enriched cell population sedimented at $62 \mathrm{~S}$. A second peak smaller than $37 \mathrm{~S}$ was noted but not analysed further. The rest of the pachytene DNA and all of the DNA from other stages sedimented at $108 \mathrm{~S}-200 \mathrm{~S}$. The S values of double-stranded DNA exceeded 250, and no change with meiotic stage was noted. The sensitivity of DNA synthesis in vivo to hydroxyurca at various stages during meiotic prophase was examined using autoradiographic and biochemical analysis. A dramatic inhibition of $\mathrm{S}$ phase incorporation was observed whereas a partial inhibition (perhaps a consequence of contamination by $S$ phasc cells) of pachytene incorporation was seen. The radioactivity in P DNA occurred in multiple peaks in caesium chloride gradients similar to the distribution found in Lilium. Two experiments indicated that the incorporation was due to repair synthesis. When labelled in vivo in the presence of BUdR, S phase cells incorporated label predominantly in heavy strands whereas pachytene cells incorporated label predominantly in light strands. If in vivo incorporation of BUdR occurred during $\mathrm{S}$ phase and subsequent synthesis during pachytene was monitored with ${ }^{3} \mathrm{H}$ incorporation, the label appeared in both heavy and light strands. The pachytene synthesis was shown to occur predominantly in repeated sequences.

In conclusion, the similar spacing of the nicks in pachytene DNA from lilies and mice and the similar occurrence of pachytene repair replication in repeated sequences argue strongly that these features may be common to pachytene metabolism in higher eukaryotes. However, the relatively uniform spacing of these nicks, their abundance, and the repetitive nature of $\mathrm{P}$ DNA raise questions concerning the relevance of these processes for meiosis. The simplest hypothesis, that this nicking and repair replication represent genetic recombination at $1 \times 10^{6}$ sites spaced at regular intervals of $2 \times 10^{5}$ base pairs but leading to only 36 reciprocal exchanges, seems highly unlikely. Stern and Hotta (1973) favour the idea that repair synthesis in repetitive DNA facilitates homologous strand matching in preparation for crossing-over, and the excess of these preparative events is necessary to ensure at least 36 reciprocal exchanges. Since pachytenc metabolism in yeast is accompanied by far less nicking and by repair replication which is very sensitive to hydroxyurea, recombination can be accomplished with far less preparation. Although a similar frequency of nicks and repair events was observed in these experiments, it is possible that totally different processes were responsible. The nicking could be an artifact arising, for example, from a periodic association of chromatin with the synaptonemal complex and these associations might render the DNA liable to nicking when the proteins are removed. The repair synthesis may not occur at such regular intervals, and some of the synthesis may be necessary for processes other than recombination. For example, P DNA synthesis may be relevant to 
proper disjunction of chromosomes in anaphase II as Roth and Ito (1967) observed abnormal second division segregation when DNA synthesis was inhibited with deoxyadenosine during pachytene, although metaphase I and anaphase I were not affected. They postulated that P DNA synthesis might be necessary for normal centromere and/or chromatid separation in anaphase II. Ito et al. (1967) observed chromatid breaks in anaphase II as a consequence of inhibiting DNA synthesis during pachytene. An interesting observation has been reported concerning the nucleosome subunit of chromatin undergoing pachytene DNA synthesis. Endogenous P DNA was recovered in a 70-100 base pair fraction after treatment with micrococcal nuclease, whereas pachytene label incorporated after irradiation was recovered in the 200 base pair component (Stern and Hotta, 1977).

The interpretation that the lily and mouse patterns of pachytene DNA metabolism are directly relevant to genetic recombination appears to be at odds with the genetic evidence. Two specific predictions appear to be violated. First, nicking should occur at a limited number of specific sites. Second, repair synthesis to correct heterozygosity in hybrid DNA should occur predominantly in unique sequences. It appears unlikely that nicking and rejoining at the limited number of recombining sites in higher eukaryotes could be detected by biophysical methods in organisms with large genomes. In yeast, one nick per $4 \times 10^{5}$ base pairs was expected, and observed. In lily, a method to detect one nick per $2 \times 10^{9}$ base pairs would be required. If repair tracts were very long in eukaryotes, repair synthesis could perhaps be detected. Since repair synthesis appears to be triggered by the presence of mismatched bases, it is possible that outbred plants or mice with more heterozygosity might show higher levels of repair synthesis than inbred strains.

\section{DNA BINDING PROTEINS IMPLICATED IN REGOMBINATION OR MEIONIS}

Proteins which might facilitate the melting of DNA and the formation of hybrid DNA have been detected in meiocytes of lilies (Hotta and Stern, 1971a), rats, bulls, and humans (Hotta and Stern, 1971c; Mather and Hotta, 1977), and in vegetative cells of a smut fungus (Banks and Spanos, 1975). These proteins share many properties with the bacteriophage $T_{4}$ gene 32 protein (Alberts and Frey, 1970) which is essential for replication and recombination of $\mathrm{T}_{4}$. The protein from Ustilago maydis has been purified to apparent homogeneity and extensively characterised (Banks and Spanos, 1975). One protein molecule (MW 20,000) binds to seven to ten nucleotides of single-stranded DNA, and the binding appears to be co-operative. Each cell contains $2.5-3 \times 10^{5}$ molecules of the protein which catalyses the renaturation of DNA at physiological temperatures and also reduces the melting temperature of double-stranded DNA. The protein reacts equally well with poly $[\mathrm{d}(\mathrm{A}-\mathrm{T}) \cdot \mathrm{d}(\mathrm{A}-\mathrm{T})], \mathrm{T}_{7}$, and calf thymus DNA. The protein stimulates the initial rate of DNA synthesis by $U$. maydis DNA polymerase on a denatured template but not on a nicked template. No stimulation of $E$. coli (polymerase $\mathrm{I}$ ), Micrococcus luteus, $\mathrm{T}_{4}$, or $\mathrm{T}_{7}$ DNA polymerases was observed on either template. The stimulation is dependent on protein to DNA ratio, and no physical interaction of polymerase and binding protein has been detected. Yarranton et al. (1976) analysed the kinetics of the stimulation and concluded that the affinity of the polymerase 
for both template and triphosphates was increased by the binding protein in the presence of the single-stranded template but not in the presence of the nicked template. They propose that this difference may have physiological importance. Moore (1975a) studied a pyrimidine auxotroph (pyr $1-1$ ) which has low intracellular thymidine concentration, is sensitive to UV light, can excise thymidine dimers in DNA, but is unable to repair the resulting gap, although chromosome replication is normal (Moore, $1975 b)$. The observations could be explained if two polymerases, one for replication and one for repair, with different triphosphate affinities were present. However, a careful search has revealed only onc polymerase in Ustilago maydis (Banks et al., 1976). Yarranton et al. (1976) propose that the different behaviour of the polymerase during replication and repair could be due to the binding protein. If the binding protein is involved in chromosome replication (due to relatively long single-stranded regions in the template) but not in repair of UV damage (due to relatively short single-stranded gaps) then the polymerase may be able to carry out the former process but not the latter when triphosphate concentrations are low. Since pyr 1 - l strains undergo induced mitotic gene conversion (Moore, $1975 b$ ) which must involve repair replication, the model predicts that single-stranded regions long enough to interact with the binding protein are formed during allelic recombination. The binding protein inhibited the activity of $E$. coli exonuclease III on double-stranded DNA and also $U$. maydis DNase I on single-stranded DNA. The possible presence of the protein in meiotic cells has not been explored, nor have mutants deficient in the protein been isolated, so the significance of the protein for meiotic recombination in $U$. maydis cannot yet be assessed.

A similar protein which can catalyse the renaturation of DNA ( $R$ protein) has been isolated from nuclear membranes of Lilium meiocytes and partially purified (Hotta and Stern, 1971a). This protcin was found in a heavy lipoprotein fraction unique to cells in meiotic prophase. Other DNA binding proteins found in lighter lipoprotein fractions in somatic and meiotic cells were not analysed, so it is possible that this protein is present in somatic and meiotic cells, but its intranuclear distribution is altered in meiocytes. Nuclear DNA binding protein activity rises during meiotic prophase to a peak in zygotene-pachytene, and the activity falls thereafter. If zygotene cells are treated with colchicine, synapsis is halted although paired regions are not disrupted, the $\mathrm{R}$ protein does not enter the lipoprotein complcx (presumably due to the interaction of colchicine with a colchicine binding protcin in the complex), but Z DNA synthesis occurs normally (Hotta and Shepard, 1973; Shepard et al., 1974). Although both replicating $\mathrm{Z}$ DNA and R protein appear in the same complex, their functional relationship remains unclear.

A protein similar to the lily $\mathrm{R}$ protein was detected in rat, bull and human nuclei (Hotta and Stern, 1971c) and has been isolated from rat spermatocyte nuclei (Mather and Hotta, 1977). The protein is sensitive to phosphorylation, and activity can be restored by dephosphorylation. The protein gave a positive glucosamine test, and may be a glycoprotein. The subcellular location of the lily and rat proteins and the relative absence of the lily protein during premeiotic $\mathrm{S}$ and mid-pachytene suggest that these proteins may not be necessary for DNA replication, hybrid DNA formation, or repair synthesis following recombination as has been postulated for the 
gene 32 protein and $U$. maydis DNA binding protein. Since many DNA binding proteins have been found in these cells, further analysis of other DNA binding proteins may reveal activities whose functions correspond more closely in the two systems.

\section{BiochemicAl DETECTION OF HYBRID DNA}

The formation of hybrid DNA during recombination in somatic cells has been demonstrated biochemically using density labelling techniques (Rommelaere and Miller-Faures, 1975; Moore and Holliday, 1976). Rommelaere and Miller-Faures grew Chinese hamster cells to $\mathrm{G}_{0}$ arrest in light medium and transferred these to medium containing ${ }^{3} \mathrm{H}$ bromodeoxyuridine (BUdR) for less than one generation. When analysed on neutral caesium chloride gradients, such DNA should band at a density intermediate between unsubstituted (LL) and fully substituted $(\mathrm{HH})$ positions if no recombination occurs. However some DNA was found at a density between the expected position (HL) and HH. This DNA was shown not to be an artifact resulting from bacterial or mitochondrial contamination, nor was it crosslinked palindromic, or low $\mathrm{G}+\mathrm{C} \mathrm{DNA}$, although it could have arisen from preferential degradation of the light strand followed by repair synthesis in heavy medium. The amount of presumptive hybrid DNA detected was 10 times the amount predicted from the number of recombination events observed using autoradiography. In Moore and Holliday's experiments, the cells were grown in heavy medium for less than one generation and shifted to light medium so that any further synthesis or repair could not produce molecules heavier than HL. They showed that treatment of the cells with mitomycin $\mathrm{C}$ increased the frequency of exchanges between chromatids (as determined by differential staining [Korenberg and Freedlender, 1974]) and also increased the amount of DNA banding between the $\mathrm{HL}$ and $\mathrm{HH}$ positions. However, the amount of hybrid DNA detected was 17-25 times the amount predicted from the observed number of exchanges. They suggest that non-reciprocal exchanges, which would not be visible cytologically, could contribute to the amount of hybrid DNA formed, and both groups acknowledge the possible influence of ${ }^{3} \mathrm{H}$ in inducing exchanges. This biochemical method appears to be more sensitive than the autoradiographic or staining techniques which have been used to detect exchanges cytologically (Taylor, 1958; Latt, 1974). Both groups estimate that the hybrid DNA regions are approximately 20,000 base pairs in length. The recombination events which generated this hybrid DNA probably occurred between newly replicated chromatids and not between homologous chromosomes. After induction with mitomycin $\mathrm{C}$, mitotic allelic recombination between homologous chromosomes has not been conclusively demonstrated (Gladstone et al., 1976; Tarrant and Holliday, 1977) although quadriradial chromosomes have been observed after such treatment (Shaw and Cohen, 1965; Huttner and Ruddle, 1976). Spontaneous mitotic recombination in mammalian cells has not been observed (Gladstone, et al., 1976; Tarrant and Holliday, 1977).

Direct visualisation of hybrid DNA in recombining molecules comparable to studies in prokaryotes (Benbow et al., 1975; Valenzuela and Inman, 1975; Potter and Dressler, 1976) has not been achieved although Simchen and Friedmann (1975) have observed unusual molecules during meiosis in yeast.

$39 / 2-\mathbf{B}$ 
The structures observed by Potter and Dressler (1976) are compatible with the formation of a single half-chromatid chiasma which can migrate along the DNA. If confirmed by observation in eukaryotes, these structures would rule out the presence of migrating bubbles of hybrid DNA as have been proposed by Sobell (1972, 1975). Karrer and Gall (1976) have reported that the free ribosomal genes in Tetrahymena can adopt a cruciform structure when incubated in vitro since these molecules are giant palindromes. The junction between the four arms of this cruciform is formally equivalent to the half-chromatid chiasma intermediate. Such molecules may be appropriate structures for the analysis of branch migration and hybrid DNA resolution by endonuclease activity in eukaryotes.

\section{A Single STRAND SPEGific NUGLEASE IMPLiGATED IN GENE GONVERSION}

A combined genetic and biochemical analysis of DNase I from Ustilago maydis has strongly implicated this enzyme in mitotic gene conversion. Using a plate test, Badman (1972) isolated recessive mutants deficient in extracellular nuclease activity (nuc-1). Mutants deficient in intracellular nuclease activity (nuc-2) were isolated from the extracellular mutants. These double mutant strains were deficient in both spontaneous and UV induced mitotic allelic recombination (which proceeds via gene conversion in Ustilago [Holliday, 1966]). However, allelic recombination in meiosis is not reduced to the same extent (Holliday and Dickson, personal communication), contrary to the early report of Badman (1972). Spontaneous and UV induced mitotic crossing-over occurred at control frequencies, and meiotic crossing-over also appeared to be unaffected. Holloman and Holliday (1973) described two nucleases in crude extracts of vegetative cells and purified one of these (DNase I) 8600-fold. Neither activity was reduced in nuc-1 strains but both were reduced in the nuc-1 nuc-2 double mutants. Two segregating factors were responsible for the mitotic allelic recombination deficiency (Holliday et al., 1974). The recombination deficiency segregated with the nuclease deficiency measured in crude extracts (Holloman and Holliday, 1973), although the plate test was unreliable in demonstrating the nuclease deficiency.

Holloman and Holliday (1973) and Holloman (1973) characterised DNase $I$ and concluded that it was a single strand specific endonuclease which could introduce nicks into double-stranded DNA with low frequency and appeared to require free ends for activity (although this property could not be confirmed [Pukkila, unpublished observations]). It required a divalent cation, had a $p \mathrm{H}$ optimum of 8.0 , left $5^{\prime}$ phosphate groups in DNA, and was sensitive to mercaptoethanol. Ahmad et al. (1975) demonstrated that the cnzyme preferentially inactivated phage SPPI heteroduplex DNA molecules with a presumptive single base substitution. The enzyme also introduces single-strand nicks in heteroduplex molecules prepared from $\phi$ 80 phage derivatives which contain single base mismatches within the $E$. coli tRNA ${ }_{1}^{\text {tyr }}$ gene (Pukkila, unpublished observations). Since the mutant tRNAs have been sequenced (Smith, 1976), the precise nature of the single base mismatch and surrounding sequence can be deduced. Several mismatches have been tested and the enzyme does not appear to recognise these with equal efficiency. Such a property is not unexpected since gen- 
etic analysis has revealed site-specific differences in frequency and direction of conversion (Rossignol, 1969). The enzyme appears to recognise a gap opposite a nick and introduce a second cut producing a double-strand break. If the enzyme is involved in gene conversion, it is clear that this double-strand cutting must be prevented in the cell. Similar properties have been described for Aspergillus $\mathrm{S}_{1}$ nuclease (Weigand et al., 1975; Shenk et al., 1975). Since mutants deficient in $S_{1}$ have not been isolated, the function of this enzyme remains unclear.

$U$. maydis DNase I may function in gene conversion by recognising a mismatched base and nicking the DNA. Exonucleolytic degradation and repair synthesis would result in gene conversion. Since the purified $U$. maydis DNA polymerase has an associated $3^{\prime}-5^{\prime}$ exonuclease which can remove a mismatched base at the end of the primer (Yarranton and Banks, 1977), removal of the incorrect base and insertion of the correct base could be accomplished by this enzyme. Gene conversion has been shown to decrease postmeiotic segregation at a closely linked site (Leblon and Rossignol, 1973) implying that hybrid DNA is a common intermediate in both processes and that if repair of mismatched bases does not occur within a region of heterozygosity, postmeiotic segregation will result. Thus, the nuc-1 nuc-2 double mutant strains which are deficient in DNase I might show increased postmeiotic segregation. A simplified method to detect postmeiotic segregation without tetrad analysis has been developed by Holliday and Dickson (1977), which hopefully can be used to test this prediction.

Acknowledgments.-I thank R. Holliday for helpful criticisms of the manuscript. This investigation was supported by the National Institutes of Health National Research Service Award GM 05430 from the Institute of General Medical Sciences.

\section{References}

AHmad, A., Holloman, W. K., AND holliday, R. 1975. Nuclease that preferentially inactivates DNA containing mismatched bases. Nature, 258, 54-56.

ALbERTS, B. M., AND FREY, L. 1970. T $_{4}$ bacteriophage gene 32: A structural protein in the replication and recombination of DNA. Nature, 227, 1313-1318.

BAASE, W. A., AND WANG, J. c. 1974. An $\omega$ protein from Drosophila melanogaster. Biochemistry $13,4299-4303$.

BADMAN, R. 1972. DNase-deficient mutants of Ustilago maydis with altered recombination frequencies. Genet. Res., 20, 213-229.

BAKER, B. S., GARPENTER, A. T. C., ESPOStTO, M. S., ESPOSITO, R. E., AND SANDleR, L. 1976. The genetic control of meiosis. Ann. Rev. Genet., 10, 53-134.

BANKs, G. R., HOlloman, w. K., KAIRIS, M. v., SPANOS, A., AND YARRANTON, G. T. 1976. A DNA polymerase from Ustilago maydis. 1. Purification and properties of the polymerase activity. Eur. 7. Biochem., 62, 131-142.

BANKS, G. R. AND SPANOS, A. 1975. The isolation and properties of a DNA-unwinding protein from Ustilago maydis. 7. Mol. Biol., 93, 63-77.

BENBOW, R. M., ZUCCARELLI, A. J., AND SINSHEIMER, R. L. 1975. Recombinant DNA molecules of bacteriophage $\phi X$ 174. Proc. Natl. Acad. Sci., 72, 235-239.

BENYAJATI, C., AND WORCEL, A. 1976. Isolation, characterization, and structure of the folded interphase genome of Drosophila melanogaster. Cell, 9, 393-407.

BogdANOV, Y. F., LIAPUNOVA, N. A., SHERUDIlo, A. I., AND ANTROPOVA, E. N. 1968 . Uncoupling of DNA and histone synthesis prior to prophase I of meiosis in the cricket Grillus (Acheta) domesticus. Exptl. Cell Res., 52, 59-70.

BUSS, M. E., AND HENDERSON, s. A. 1971. Induced bivalent interlocking and the course of meiotic chromosome synapsis. Nature New Biol. 234, 243-246.

BYERS, B., AND GOETSCH, L. 1975. Electron microscopic observations in the meiotic karyotype of diploid and tetraploid Saccharomyces. Proc. Natl. Acad. Sci., 72, 5056-5060. 
CAllan, H. G. 1972. Replication of DNA in the chromosomes of eukaryotes. Proc. $R$. Soc. Lond. B., 181, 19-41.

CAllan, H. G. 1973. DNA replication in chromosomes of eukaryotes. Cold Spring Harb. Symp. Quant. Biol., 38, 195-204.

CAllan, H. G., AND PERRY, p. E. 1977. Recombination in male and female meiocytes contrasted. Phil. Trans. R. Soc. Lond. B., 277, 227-233.

CALlAN, H. G., AND TAYLOR, J. H. 1968, A radioautographic study of the time course of male meiosis in the newt, Triturus vulgaris. 7. Cell Sci., 3, 615-626.

CARPENTER, A. T. C. 1975a. Electron microscopy of meiosis in Drosophila melanogaster females. I. Structure, arrangement, and temporal change of the synaptonemal complex in wild type. Chromosoma, 51, 157-182.

CARPENTER, A. T. C. 1975b. Electron microscopy of meiosis in Drosophila melanogaster females. II. The recombination nodule-a recombination associated structure at pachytene? Proc. Nall. Acad. Sci., 72, 3186-3189.

ChAmpoux, J. J., AND DUlbecCo, R. 1972. An activity from mammalian cells that untwists superhelical DNA--a possible swivel for DNA replication. Proc. Natl. Acad. Sci., 69, $143-146$.

Chandley, A. c. 1968. The effect of X-rays on female germ cells of Drosophila melanogaster. III. A comparison with heat treatment on crossing over in the $\mathrm{X}$ chromosome. Mutation Res., 5, 93-107.

CHANDLEY, A. C., HOTTA, Y., AND STERN, II. 1977. Biochemical analysis of meiosis in the male mouse. I. Separation and DNA labelling of specific spermatogenic stages. Chromosoma (in press).

CHIU, s. M., AND hastings, P. J. 1973. Premeiotic DNA synthesis and recombination in Chlamydomonas reinhardi. Genetics, 73, 29-43.

DAVIES, D. R., AND LAWRENCE, C. W. 1967. The mechanism of recombination in Chlamydomonas reinhardi. II. The influence of inhibitors of DNA synthesis on intergenic recombination. Mutation Res., 4, 147-154.

DICKINSON, H. G., AND HESLOP-HARRISON, J. 1977. Ribosomes, membranes, and organelles during meiosis in angiosperms. Phil. Trans. R. Soc. Lond. B., 277, 327-342.

DOVER, G. A., AND RILEY, R. 1973. The effect of spindle inhibitors applied before meiosis on meiotic chromosome pairing. 7. Cell Sci., 12, 143-161.

DRISCOLL, C. J., AND DARVEY, N. L. 1970. Chromosome pairing: Effect of colchicine on an isochromosome. Science, 169, 290-291.

DUdLey, P. L. 1973. Synaptonemal polycomplexes in spermatocytcs of the gooseneck barnacle, Pollicipes polymerus Sowerby (Crustaeca: cirripedia). Chromosoma, 40, 221-242.

ESPONDA, P., AND STOCKERT, J. C. 1971. Localization of RNA in the synaptonemal complex. 7. Ultrastruct. Res., 35, 411-417.

ESPOSTTO, R. E., AND ESPOSITO, M. S. 1974. Genetic recombination and commitment to meiosis in Saccharomyces. Proc. Natl. Acad. Sci., 71, 3172-3176.

FIIL, A., AND MOENS, P. B. 1973. The development, structure, and function of modified synaptonemal complexes in mosquito oocytes. Chromosoma, 41, 37-62.

FINCHAM, J. R. s., AND HOLLIDAY, R. 1970. An explanation of fine strueture map expansion in terms of excision repair. Molec. Gen. Genet., 109, 309-322.

FLAVEIX, R. B., AND WALKER, G. W. R. 1973. The occurrence and role of DNA synthesis during meiosis in wheat and rye. Exptl. Cell Res., 77, 15-24.

FOGEL, s., HURST, D. D., AND MORTIMER, R. K. 1971. Gene conversion in unselected tetrads from multipoint crosses. The Second Stadler Symposium 89-110, University of Missouri.

FOGEI, s., AND MORTIMER, R. K. 1969. Information transfer in meiotic gene conversion. Proc. Natl. Acad. Sci., 62, 96-103.

FOGEL, s., AND MORTIMER, R. K. 1970. Fidelity of gene conversion in yeast. Molec. Gen Genet., 109, 177-185.

FOGEL, s., AND MORTIMER, R. K. 1974. Gene conversion and mismatched base repair in hybrid DNA. Genetics, 77 (Suppl), 522.

Gili.irs, c. B. 1972. Rcconstruction of the Neurospora crassa pachytene karyotype from serial sections of synaptonemal complexes. Chromosoma, 36, 119-130.

GII.LIES, c. B. 1973. Ultrastructural analysis of maize pachytene karyotypes by three dimensional reconstruction of the synaptonemal complexes. Chromosoma, 43, 145176.

GILlIES, C. B. 1974. The nature and extent of synaptonemal complex formation in haploid barley. Chromosoma, 48, 441-453. 
GILlies, C. B. 1975. Synaptonemal complex and chromosome structure. Ann. Rev. Genet. 9, 91-109.

Gladstone, P., SABO, K., PIOUS, L., AND PIOUS, D. 1976. Correlation between production of quadrilateral chromosome configurations and mitotic recombinants in the HLA region in cultured lymphoid cells. Proc. V Int. Cong. Human Genetics Exerpta Medica (Amsterdam) Int. Congr. Series No. 397, p. 127.

GRelL, R. F. 1969. Meiotic and somatic pairing. In Genetic Organization, ed. E. W. Caspari and A. W. Ravin, vol. I, pp. 361-492. Academic Press, New York.

Hastings, P. J. 1975. Some aspects of recombination in eukaryotic organisms. Ann. Rev. Genet., 9, 129-144.

IIECHT, N. B., AND STERN, H. 1971. A late replicating DNA protein complex from cells in meiotic prophase. Exptl. Cell Res., 69, 1-10.

henderson, s. A. 1970. The time and place of meiotic crossing over. Ann. Rev. Genet., 4, 295-324.

HEWISH, D. R., AND BURGOYNE, L. A. 1973. Chromatin sub-structure. The digestion of chromatin DNA at regularly spaced sites by a nuclear deoxyribonuclease. Biochem. Biophys. Res. Comm., 52, 504-510.

holliday, R. 1964. A mechanism for gene conversion in fungi. Genet. Res., 5, 282-304.

HOLI.IDAY, R. 1966. Studies on mitotic gene conversion in Ustilago maydis. Genet. Res., 8, 323-337.

HOLLIDAY, R. 1968. Genetic recombination in fungi. In Replication and Recombination of Genetic Material, ed. W. J. Peacock and R. D. Brock, pp. 157-174. Australian Academy of Science, Canberra.

HOLLIDAY, R. 1971. Biochemical measure of the time and frequency of radiation-induced allelic recombination in Ustilago. Nature New Biol., 232, 233-236.

HOLLIDAY, R. 1974. Molecular aspects of genetic exchange and gene conversion. Genetics, $78,273-287$.

holliday, R. 1977. Recombination and meiosis. Phil. Trans. R. Soc. Lond. B., 277, 359-370.

HOLlidAy, R., AND DICKSON, J. M. 1977. The detection of post-meiotic segregation without tetrad analysis in Ustilago maydis: Evidence that a mutation defective in excision of pyrimidine dimers can repair mismatched bases in hybrid DNA. Molec. Gen. Genet. (in press).

holliday, R., holloman, w. K., Banks, G. R., UnRAU, P., AND PUgh, J. E. 1974. Genetic and biochemical studies of recombination in Ustilago maydis. In Mechanisms in Recombination, ed. R. F. Grell, pp. 239-262. Plenum Press, New York.

HOLlidAY, R., AND WHItEHOyse, H. L. K. 1970. The wrong way to think about gene conversion? Molec. Gen. Genet., 107, 85-93.

holloman, w. K. 1973. Studies on a nuclease from Ustilago maydis. II. Substrate specificity, and mode of action of the enzyme. 7. Biol. Chem., 248, 8114-8119.

HOlloman, W. K., AND holliday, R. 1973. Studies on a nuclease from Ustilago maydis. I. Purification, properties, and implication in recombination of the enzyme. $\mathcal{F}$. Biol. Chem., 248, 8107-8113.

HOTTA, Y., CHANDLEY, A. L., AND STERN, H. 1977. Biochemical analysis of meiosis in the male mouse. II. DNA metabolism at pachytene. Chromosoma (in press).

hotta, y., Ito, M., AND stern, H. 1966. Synthesis of DNA during meiosis. Proc. Natl. Acad. Sci., 56, 1184-1191.

hotta, y., Parchman, L. G., And stern, H. 1968. Protein synthesis during meiosis. Proc. Natl. Acad. Sci., 60, 575-582.

HOTTA, Y., AND SHEPARD, J. 1973. Biochemical aspects of colchicine action on meiotic cells. Molec. Gen. Genet., 122, 243-260.

hotTA, y., AND stern, H. $1971 a$. A DNA binding protein in meiotic cells of Lilium. Devel. Biol., 26, 87-99.

HOtTA, Y., AND STERN, H. 1971b. Analysis of DNA synthesis during meiotic prophase in Lilium. 7. Mol. Biol., 55, 337-355.

hotTA, Y., AND STERN, H. 1971c. Meiotic protein in spermatocytes of mammals. Nature New Biol., 234, 83-86.

HOTTA, Y., AND STERN, H. 1974. DNA scission and repair activities during pachytene in Lilium. Chromosoma, 46, 279-296.

HOTTA, Y., AND STERN, H. 1975. Zytogene and pachytene labeled sequences in the meiotic organization of chromosomes. In The Eukaryotic Chromosome, ed. W. J. Peacock and R. D. Brock, pp. 283-300. Australian National University Press, Canberra. 
ноTtA, х., AND Stern, н. 1976. Persistent discontinuities in late replicating DNA during meiosis in Lilium. Chromosoma, 55, 171-182.

HOWELL, S. H., AND STERN, H. 1971. The appearance of DNA breakage and repair activities in the synchronous meiotic cycle of Lilium. 7. Mol. Biol., 55, 357-378.

HURST, D. D., FOGEL, S., AND MORTIMER, R. K. 1972. Conversion-associated recombination in yeast. Proc. Natl. Acad. Sci., 69, 101-105.

HUTTNER, K. M., AND RUDDLE, F. H. 1976. Study of mitomycin-C induced chromosomal exchange. Chromosoma, 56, 1-13.

ITO, M., AND HOTTA, Y. 1973. Radioautography of incorporated ${ }^{3} \mathrm{H}$-thymidine and its metabolism during meiotic prophase in microsporocytes of Lilium. Chromosoma, 43, 391-398.

ITO, M., HOTTA, Y., AND STERN, H. 1967. Studies of meiosis in vitro. II. Effect of inhibiting DNA synthesis during meiotic prophase on chromosome structure and behavior. Devel. Biol., 16, 54-77.

JACOBSON, G. K., PINON, R., ESPOSITO, R. E., AND ESPOSITO, M. s. 1975. Single strand scissions of chromosomal DNA during commitment to recombination at meiosis. Proc. Natl. Acad. Sci., 72, 1887-1891.

JEGGO, P. 1973. DNA polymerases of mutant and wild type strains of Ustilago maydis. Ph.D. Thesis, Council for National Academic Awards, London.

KARRER, K. M., AND GALL, J. G. 1976. The macronuclear ribosomal DNA of Tetrahymena pyriformis is a palindrome. 7. Mol. Biol., 104, 421-453.

KELLER, w. 1975. Characterization of purified DNA-relaxing enzyme from human tissue culture cells. Proc. Natl. Acad. Sci., 72, 2550-2554.

KITANI, Y., Olive, L. S., AND El ANI, A. S. 1962. Genetics of Sordaria fimicola B. Aberrant segregation at the $g$ locus. Am. F. Bot., 49,697-706.

KOFMAN-ALFARO, s., AND CHANDLEY, A. c. 1970. Meiosis in the male mouse. An autoradiographic investigation. Chromosoma, 31, 404-420.

KOFMAN-ALFARO, s., AND GHANDLEY, A. c. 1971. Radiation induced synthesis in spermatogenic stages of the mouse. Exptl. Cell Res., 69, 33-44.

KORNBERG, R. D. 1974. Chromatin structure: A repeating unit of histones and DNA. Science, 184, 868-871.

KORENBERG, J. R., AND FREEDLENDER, E. F. 1974. Giemsa technique for the detection of sister chromatid exchanges. Chromosoma, 48, 355-360.

KUENZI, M. T., AND ROTH, R. 1971. Timing of mitochondrial DNA synthesis during meiosis in Saccharomyces cerevisiae. Exptl. Cell Res., 85, 377-382.

LATT, S. A. 1974. Sister chromatid exchanges, indices of human chromosome damage and repair: detection by fluorescence and induction by mitomycin C. Proc. Natl. Acad. Sci., $71,3162-3166$.

LAWRENCE, c. W. 1965. Influence of non-lethal doses of radiation on recombination in Chlamydomonas reinhardi. Nature, 206, 789-791.

LAWRENCE, C. W. 1967. Influence of non-lethal doses of radiation on allelic recombination in Chlamydomonas reinhardi. Genet. Res., 9, 123-127.

LEblon, G. 1972a. Mechanisms of gene conversion in Ascobolus immersus. I. Existence of a correlation between the origin of mutants induced by different mutagens and their conversion spectrum. Molec. Gen. Genet., 115, 36-48.

LEblon, G. 1972b. Mechanism of gene conversion in Ascobolus immersus. II. The rclationships between the genetic alterations in $b_{1}$ or $b_{2}$ mutants and their conversion spectrum. Molec. Gen. Genet., 116, 322-335.

LEBlon, G., AND ROSSIGNOL, J. L. 1973. Mechanism of gene conversion in Ascobolus immersus. III. The interaction of heteroalleles in the conversion process. Molec. Gen. Genet., 122, 165-182.

LINDEGREN, c. C. 1953. Gene conversion in Saccharomyces. 7. Genet., 51, 625-637.

Lissouba, P., MousseaU, J., Rizet, G., AND Rossignol, J. L. 1962. Fine structure of genes in the ascomycete Ascobolus immersus. Adv. Genet., 11, 343-380.

LU, B. C. 1974. Genetic recombination in Coprinus. IV. A kinetic study of the temperature effect on recombination frequency. Genetics, 78, 661-677.

LU, B. C., AND CHIU, s. M. 1976. Genetic recombination in Coprinus. V. Repair synthesis of deoxyribonucleic acid and its relation to meiotic recombination. Molec. Gen. Genet., 147, 12 I-128.

LU, B. C., AND JENG, D. Y. 1975. Meiosis in Coprinus. VII. The prekaryogamy S-phase and the postkaryogamy DNA replication in C. lagopus. F. Cell Sci., 17, 461-470.

MAGUIRE, M. P. 1965. The relationship of crossover frequency to synaptic completion at pachytene in maize. Genetics, 51, 23-40. 
MAGUiRE, M. P. 1966. The relationship of crossing over to chromosome synapsis in a short paracentric inversion. Genetics, 53, 1071-1077.

MAguire, M. P. 1972. The temporal sequence of synaptic initiation, crossing over, and synaptic completion. Genetics, 70, 353-370.

maguire, м. P. 1977. Homologous chromosome pairing. Phil. Trans. R. Soc. Lond. B., $277,245-258$.

MATHER, J., AND HOTTA, y. 1977. A phosphorylatable DNA-binding protein associated with a lipoprotein fraction from rat spermatocyte nuclei. Exptl. Cell Res. (in press).

MATTOCCIA, E., GANDINI ATTARDI, D., AND TOCCHINI-VALENTINI, G. P. 1976. DNA relaxing activity and endonuclease activity in Xenopus laevis oocytes. Proc. Natl. Acad. Sci., 73, $455 \mathrm{I}-4554$

MEISTRICH, M. L., REID, B. O., AND BARCELlonA, w. J. 1975. Meiotic DNA synthesis during mouse spermatogenesis. 7. Cell Biol., 64, $211-222$.

MESELSON, M. 1972. Formation of hybrid DNA by rotary diffusion during genetic recombination. 7. Mol. Biol., 71, 795-798.

MESElSON, M. S., AND RADDING, C. M. 1975. A general model for genetic recombination. Proc. Natl. Acad. Sci., 72, 358-361.

Mitchell, м. в. 1955. Aberrant recombination of pyridoxine mutants of Neurospora. Proc. Natl. Acad. Sci., 41, 215-220.

moens, P. B. 1968. The structure and function of synaptonemal complexes in Lilium longiflorum sporocytes. Chromosoma, 23, 418-451.

MOENS, P. B. 1969 . The fine structure of meiotic chromosome polarization and pairing in Locusta migratoria spermatocytes. Chromosoma, 28, 1-25.

MOENS, P. B. 1973. Quantitative electron microscopy of chromosome organization at meiotic prophase. Cold Spring Harb. Symp. Quant. Biol., 38, 99-107.

MOORE, C. W., AND SHERMAN, F. 1975. Role of DNA sequences in genetic recombination in the iso-l-cytochrome $\mathrm{c}$ gene of yeast. I. Discrepancies between physical distance and genetic distances determined by five mapping procedures. Genetics, 79, 397-418.

MOORE, C. W., AND SHERMAN, F. 1977. Role of DNA sequences in genetic recombination in the iso-I-cytochrome $c$ gene of yeast. II. Comparison of mutants altered at the same and nearby base pairs. Genetics, $85,1-22$.

MOORE, P. D. 1975a. Radiation-sensitive pyrimidine auxotrophs of Ustilago maydis. I. Isolation and characterization of mutants. Mutation Res., 28, 355-366.

MOORE, P. D. 1975b. Radiation-sensitive pyrimidine auxotrophs of Ustilago maydis. II. A study of repair mechanisms and UV recovery in pyr I. Mutation Res., 28, 367-380.

MOORE, P. D., AND HOLlidAy, R. 1976. Evidence for the formation of hybrid DNA during mitotic recombination in Chinese hamster cells. Cell, 8, 573-579.

moses, M. J. 1968. Synaptinemal complex. Ann. Rev. Genet., 2, 363-412.

MURRAY, N. E. 1968. Polarized intragenic recombination in chromosome rearrangements of Neurospora. Genetics, 58, 181-191.

NADLER, K. D. 1976. Histone acetylation during meiosis in Lilium microsporocytes. Exptl. Cell Res., 101, 283-292.

NOLL, M. 1974. Subunit structure of chromatin. Nature, 251, 249-252.

Olins, A. L., AND OlINs, D. E. 1974. Spheroid chromatin units ( $\delta$ bodies). Science, 183, $330-333$.

Olrve, L. s. 1959. Aberrant tetrads in Sordaria fimicola. Proc. Natl. Acad. Sci., 45, 727-732.

PARCHMAN, L. G., AND STERN, H. 1969. The inhibition of protein synthesis in meiotic cells and its effect on chromosome behavior. Chromosoma, 26, 298-311.

PASZEWSKI, A. 1970. Gene conversion: Observations on the DNA hybrid models. Genet. Res., 15, 55-64.

PEACOCK, W. J. 1968. Chiasmata and crossing over. In Replication and Recombination of Genetic material, ed. W. J. Peacock and R. D. Brock, pp. 229-241. Australian Academy of Science, Canberra.

PEACOCK, w. J. 1970. Replication, recombination, and chiasmata in Goniaea australatae (Orthoptera Acrididae). Genetics, 65, 593-617.

PINON, R., SALTS, Y., AND sIMCHEN, G. 1974. Nuclear and mitochondrial DNA synthesis during yeast sporulation. Exptl. Cell Res., 83, 231-238.

POTTER, H., AND DRESSLER, D. 1976. On the mechanism of genetic recombination: electron microscopic observation of recombination intermediates. Proc. Natl. Acad. Sci., 73, 3000-3004.

PUкKILA, P. J. 1975. Identification of the lampbrush chromosome loops which transcribe 5S ribosomal RNA in Notophthalmus (Triturus) viridescens. Chromosoma, 53, 71-89. 
RASMUSSEN, s. w. 1975. Synaptonemal polycomplexes in Drosophila melanogaster Meigen. Chromosoma, 49, 321-331.

RASMUSSEN, s. w. 1976. The meiotic prophase in Bombyx mori females analyzed by three dimensional rcconstructions of synaptonemal complexes. Chromosoma, 54, 245-293.

RHOADES, м. м. 1968. Studies on the cytological basis of crossing over. In Replication and Recombination of Genetic Material, ed. W.J. Peacock and R. D. Brock, 229-241. Australian Academy of Science, Canberra.

RILEY, R., AND BENNET, M. D. 1971. Meiotic DNA synthesis. Nature, 230, 182-185.

ROMMELAERE, J., AND MILLER-FAURF, A. 1975. Detection by density equilibrium centrifugation of recombinant-like DNA molecules in somatic mammalian cells. 7 . Mol. Biol., 98, 195-218.

ROSSEN, J. M., AND WFSTFRGAARD, M. 1966. Studies on the mechanism of crossing over. II. Meiosis and the time of meiotic chromosome replication in the ascomycete Neottiella rutilans (Fr.) Dennis. Cr. Trav. Lab. Carlsberg, 35, 233-260.

Rossignol, J. L. 1969. Existence of homogeneous categories of mutants exhibiting various conversion patterns in gene 75 of Ascobolus immersus. Genetics, 63, 795-805.

Rотн, T. F. 1966. Changes in the synaptinemal complex during meiotic prophase in mosquito oocytes. Protoplasma, 61, 346-386.

RO'H, T. F., AND ITO, м. 1967. DNA dependent formation of the synaptinemal complex at mciotic prophase. 7. Cell. Biol., 35, 247-255.

SEARs, E. R. 1976. Genetic control of chromosome pairing in wheat. Ann. Rev. Genet., 10, 31-51.

SEN, s. K. 1969. Regulation of chiasma frequency in Lilium microsporocytes in vitro. Nature $224,178-179$.

SHAW, M. W., AND COHEN, M. M. 1965. Chromosome exchanges in human leukocytes induced by mitomycin C. Genetics, 51, 181-190.

SHENK, T. E., RHODES, G., RIGBY, P. W. J., AND BFRG, P. 1975. Biochemical method for mapping mutational alterations in DNA with $\mathrm{S}_{1}$ nuclease. The location of deletions and temperature sensitive mutations in Simian virus 40. Proc. Natl. Acad. Sci., 72, 989-993.

SHEPARD, J., BOOTHROYD, E. R., AND STERN, H. 1974. The effect of colchicine on synapsis and chiasma formation in microsporocytes of Lilium. Chromosoma, 44, 423-437.

SiIeridan, W. E., AND stern, H. 1967. Histones of meiosis. Exptl. Cell. Res., 45, 323-335.

SIGAL, N., AND ALBERTS, B. 1972. Genetic recombination: The nature of a crossed strandexchange between two homologous DNA molecules. F. Mol. Biol., 71, 789-793.

S1LVA-LOPEZ, E., LAMB, J., AND ROTH, R. 1975. Role of premeiotic DNA replication in gene conversion. Nature, 253, 212-214.

S1Mainen, G., AND FRIEDMANN, A. 1975. Structure of DNA molecules in yeast meiosis. Nature, 257, 64-66.

SIMchen, G., AND HiRSHBerg, $y$. 1977. Effects of the mitotic cell cycle mutation $c d c 4$ on yeast meiosis. Genetics (in press).

SIMGITN, G., 1DAR, D., AND KASSIR, Y. 1976. Recombination and hydroxyurea inhibition of DNA synthesis in ycast meiosis. Molec. Gen. Genet., 144, 21-27.

sMrTH, J. D. 1976. Transcription and processing of transfer RNA precursors. Prog. Nucl. Acid. Res. Mol. Biol., 16, 25-73.

SMYTH, D. R., AND STERN, H. 1973. Repeated DNA synthesized during pachytene in Lilium henryi. Nature New Biol., 245, 94-96.

sobel1, H. м. 1972. Molecular mechanism for genetic recombination. Proc. Natl. Acad. Sci., 69, 2483-2487.

SOBELL, H. M. 1973. Symmetry in protein-nucleic acid interaction and its genetic implications. Adv. in Genetics, 17, $411-\frac{4}{2} 90$.

SOBELL, H. M. 1974. Concerning the stereochemistry of strand equivalence in genetic recombination. In Mechanisms in Recombination, ed. R. F. Grell, pp. 433-438. Plenum Press, New York.

SOBEL.I. II. M. 1975. A mechanism to activate branch migration between lomologous DNA molecules in genetic recombination. Proc. Natl. Acad. Sci., 72, 279-283.

sommerville, f., AND MALCOLM, D. B. 1976. Transcription of genetic information in amphibian oocytes. Chromosoma, 55, 183-208.

STADI.R, D. R., AND TOWE, A. M. 1971. Evidence for mciotic recombination in Ascobolus involving only one member of a tetrad. Genetics, 68, 404-413.

stahil, w. W. 1969. One way to think about gene conversion? Genetics (Suppl.), 61, 114. 
STERN, H., AND HOTTA, Y. 1969. DNA synthesis in relation to chromosome pairing and chiasma formation. Genetics (Suppl.), 61, 27-39.

Stern, H., ANd hotta, y. 1973. Biochemical controls of meiosis. Ann. Rev. Genet., 7, 37-66. stern, H., AND hotta, y. 1977. Biochemistry of meiosis. Phil. Trans. R. Soc. Lond. B., $277,277-294$.

STROKov, A. A., Bogdanov, Y. F., AND RESNiKova, s. A. 1973. A quantitative study of histone in meiocytes. II. Polyacrylamide gel electrophoresis of isolated histones from Lilium microsporocytes. Chromosoma, 43, 247-260.

SUEOKA, N., CHIANG, K. S., AND KATEs, J. R. 1967. Deoxyribonucleic acid replication in meiosis of Chlamydomonas reinhardi. F. Mol. Biol., 25, 47-66.

TARRENT, G. M., AND HOLlidAY, R. 1977. A search for allelic recombination in Chinese hamster cell hybrids. Molec. Gen. Genet. (in press).

TAYLOR, J. H. 1958. Sister chromatid exchanges in tritium-labelled chromosomes. Genetics, $43,515-529$.

THURIAUX, P. 1977. Is recombination heterogeneously distributed on the eukaryotic genomes and related to their informational content. Nature (in press).

UNRAU, P., AND HOLLIDAY, R. 1972. Recombination during blocked chromosome replication in ts strains of Ustilago maydis. Genet. Res., 19, 145-155.

VAlenzUela, M. S., AND inMAN, R. B. 1975. Visualization of a novel function in bacteriophage DNA. Proc. Natl. Acad. Sci., 72, 3024-3028.

vosBerg, H. P., GROSSMAN, L. I. AND VINOGRAD, J. 1974. Superhelix relaxation protein from animal cells : partial purification using a fluorometric assay; preparation of DNAs with differing superhelix densities. Fed. Proc., 33, 1356.

WAGNER, R. E., AND RADMAN, M. 1975. A mechanism for initiation of genetic recombination. Proc. Natl. Acad. Sci., 72, 3619-3622.

WANG, J. c. 1971. Interaction between DNA and an Escherichia coli protein w. $\mathcal{F}$. Mol. Biol., 55, 523-533.

Weintraub, H., WORCEl, A., AND Alberts, B. 1976. A model for chromatin based upon two symmetrically paired half-nucleosomes. Cell, 9, 409-417.

WESTERgaARD, M., AND VON WETTSTEIN, D. 1970. Studies on the mechanism of crossing over. IV. The molecular organization of the synaptinemal complex in Neotiella (Cooke) Saccardo (Ascomycetes). Cr. Trav. Lab. Carlsberg, 37, 239-268.

WestergaARd, M., AND VON Wettstein, D. 1972. The synaptinemal complex. Ann. Rev. Genet., 6, 71-110.

Westerman, M. 1967. The effect of X-irradiation on male meiosis in Schistocerca gregaria. I. Chiasma frequency response. Chromosoma, 22, 401-416.

Whitehouse, H. L. K., AND hastings, P. J. 1965. Analysis of genetic recombination on the polaron hybrid DNA model. Genet. Res., 6, 27-92.

WIEGAND, R. C., GODSON, G. N., AND RADDING, c. M. 1975. Specificity of the $\mathrm{S}_{1}$ nuclease from Aspergillus oryzae. 7. Biol. Chem., 250, 8848-8855.

YARRANTON, G. T., AND BANKS, G. R. 1977. A DNA polymerase from Ustilago maydis. III. Evidence of proof-reading by the associated $3^{\prime}-5^{\prime}$ deoxyribonuclease activity. Eur. 7. Biochem. (in press).

YARRANTON, G. T., MOORE, P. D., AND SPANOS, A. 1976. The influence of DNA binding protein on the substrate affinities of DNA polymerase from Ustilago maydis: One polymerase implicated in both DNA replication and repair. Molec. Gen. Genet., 145, $215-218$.

yosT, H. T., AND BENNEYAN, R. N. 1957. The effects of combined radiations on crossing over in Drosophila melanogaster. Genetics, 42, 147-160.

ZICKLER, D. 1973. Fine structure of chromosome pairing in ten Ascomycetes: meiotic and premeiotic (mitotic) synaptonemal complexes. Chromosoma, 40, 401-416.

ZICKLER, D., AND OLSON, L. W. 1975. The synaptonemal complex and the spindle plaque during meiosis in yeast. Chromosoma, 50, 1-23. 